\title{
PENDAMPINGAN PENGEMBANGAN KEMAMPUAN STORY TELLING GURU KELOMPOK BERMAIN DAN TAMAN PENITIPAN ANAK AVICIENA
}

\author{
Dewanti Ratna Pertiwi \\ Teknik Mesin \\ Sekolah Tinggi Teknologi Adisutjipto \\ Jalan Janti Blok R Lanud Adisutjipto Yogyajarta \\ Email : dewantiratna@stta.ac.id
}

\begin{abstract}
Early childhood education (PAUD) is an early stage education where children are introduced to several languages other than mother tongue such as national and foreign languages. One foreign language that can be introduced is English. The introduction of English can be carried out in various ways such as singing, reading, and story telling. Story telling is believed to be able to give moral messages, introduce culture, introduce vocabulary, and stimulate children's imagination and creativity. The community service activities were carried out in the play group and day care Aviciena. The school program to develop fun reading is considered in line with the teacher storytelling capacity building activities. This activity is expected to improve the ability of teacher's story telling so that the teacher is able to bring stories not only in Indonesian but also in English. In addition, several story telling visual facilities were given to this institution to support the success of story telling activities.
\end{abstract}

Keywords: early child education, story telling

\begin{abstract}
Abstrak
Pendidikan anak usia dini (PAUD) merupakan pendidikan tahap awal di mana anak mulai dikenalkan dengan beberapa bahasa selain bahasa ibu misalnya bahasa nasional dan bahasa asing. Salah satu bahasa asing yang bisa mulai dikenalkan adalah bahasa Inggris. Pengenalan bahasa Inggris bisa dikemas dengan berbagai cara misalnya bernyanyi, membaca, dan story telling. Story telling diyakini mampu memberi pesan moral, mengenalkan budaya, mengenalkan kosa kata, dan merangsang imajinasi dan kreativitas anak. Kegiatan pengabdian kepada masyarakat ini dilaksanakan di kelompok bermain dan taman penitipan anak Aviciena. Program sekolah untuk mengembangkan fun reading dianggap selaras dengan kegiatan pengembangan kemampuan story telling guru. Pendampingan ini diharapkan mampu meningkatkan kemampuan story telling guru sehingga guru mampu membawakan cerita tidak hanya dalam bahasa Indonesia tetapi juga bahasa Inggris. Selain itu, beberapa fasilitas peraga story telling diberikan pada lembaga ini untuk mendukung kelancaran kegiatan story telling.
\end{abstract}

Kata kunci: paud, story telling

\section{Latar Belakang}

Pendidikan merupakan sarana untuk kemajuan suatu bangsa. Di Indonesia, pendidikan berawal pada jenjang pendidikan usia dini (PAUD) yang kemudian 
dilanjutkan pada pendidikan dasar. Umumnya, PAUD diikuti oleh anak usia 3 bulan hingga 7 tahun. Pada usia ini anak dipandang mengalami perkembangan kecerdasan yang pesat (golden age) baik perkembangan mental maupun fisik sehingga merupakan langkah tepat apabila lembaga PAUD memberikan input yang variatif. Selian itu, otak anak juga mampu menerima dan menyerap berbagai macam informasi sehingga perlu rangsangan yang baik. PAUD yang berkualitas diharapkan mampu membekali kesiapan anak untuk menghadapi jenjang pendidikan berikutnya dan masa depan anak tersebut.

Kegiatan PAUD umumnya menekankan aspek pengembangan bersosialisasi dan mengenal kata-kata di sekitar lingkungan anak melalui kegiatan bemain, bernyanyi, bercerita, dan menari yang disesuaikan dengan kelompok usia anak. Pada kegiatan bercerita, anak sudah dapat dikenalkan multi languages sehingga merangsang kemampuan berbahasa anak lebih lanjut. Selain bahasa Indonesia, anak dapat dikenalkan bahasa asing misalnya bahasa Inggris. Pertiwi (2019) menyebutkan bahasa Inggris merupakan bahasa internasional yang mendorong berbagai pihak untuk terus mengembangkan penguasaan bahasa ini. Demikian juga dengan instansi PAUD. Kegiatan bercerita dalam bahasa Indonesia dapat dikembangkan menjadi story telling yang diyakini mampu memberi pesan moral, mengenalkan budaya, mengenalkan kosa kata, dan merangsang imajinasi dan kreativitas anak.

Rich (2014) menyebutkan bahwa tantangan terbesar pada pembelajaran bahasa Inggris pada PAUD adalah ketika bahasa Inggris tidak digunakan sebagai bahasa ibu. Oleh karena itu, penyampaian bahasa Inggris seyogyanya menggunakan teknik yang ringan dan mudah diaplikasikan. Linse (2005) menambahkan untuk memberikan pengajaran yang paling mungkin terjangkau, guru PAUD harus mampu mengadaptasi materi sesuai perkembangan siswa didik. Hal ini juga berlaku pada pembelajaran bahasa Inggris menggunakan story telling di mana guru dapat dengan luwes mengembangkan materi apapun sesuai kondisi anak-anak didik. Garvie (1990) menyebutkan bahwa menjadi untuk menjadi story teller yang baik kadang guru menjadi aktris, mampu menggunakan bahasa tubuh tertutama mata dan suara, dan mampu menyampaikan pesan moral di balik sebuah cerita.

PAUD Aviciena terletak di lokasi strategis yaitu di Maguwo, Banguntaan, Bantul. Posisi ini mengundang minat banyak orang tua dari berbagai latar belakang menyekolahkan putra-putrinya di Aviciena. Mereka berasal dari latar belakang pekerjaan wiraswasta, pendidik, pegawai swasta, dan TNI. Hal ini membuat Aviciena selalu bersinergi untuk memberikan pengembangan program pendidikan. Tidak lepas dari kurikulum PAUD yang anak diberi kesempatan untuk mengembangkan dii sesuai kemampuan masing-masing, kegiatan story telling diharapkan mampu menambah poin positif bagi pengembangan program sekolah.

Diampu oleh sepuluh guru dan satu kepala sekolah, Aviciena memiliki enam kelompok usia yaitu kelompok bayi 3 bulan-1 tahun dengan dua guru, batita 1-2 tahun dengan dua guru, batita 2-3 tahun dengan tiga guru, balita 3-4 tahun dengan satu guru, TK A 4-5 tahun dengan satu guru, dan TK B 5-7 tahun dengan satu guru. Para guru tersebut merupakan lulusan SMA dan pada kelompok TK guru merupakan lulusan Sarjana Strata satu jurusan pendidikan agama Islam dan jurusan bahasa Arab dan kepala sekolah merupakan lulusan Strata satu jurusan psikologi. Untuk mendukung program sekolah, Aviciena juga mendatangkan guru ekstra musik, ekstra melukis, dan ekstra tahfidz. Satu tahun yang lalu, Aviciena mendatangkan guru ekstra bahasa Inggris yang merupakan mahasiswa tingkat akhir jurusan pendidikan bahasa Inggris, namun kegiatan ini vakum selama satu tahun terakhir ini karena kesulitan mencari guru. Ektra bahasa Inggris pada waktu itu menekankan aspek pengembangan kosakata melalui bermain dan lagu.

\section{Masalah}


Dalam hal kegiatan ekstra kurikuler bahasa Inggris, Aviciena mengalami kendala kurang tenaga pendidik. Tidak adanya guru ekstra bahasa Inggris menyebabkan kegiatan ekstra bahasa Inggris berhenti sehingga siswa menjadi tidak bisa mengembangkan kemampuan bahasa Inggris mereka. Masalah ini akan bisa diatasi dengan memberi pendampingan kepada guru tentang pengajaran bahasa Inggris salah satunya story telling yang dianggap cukup mudah dijangkau oleh para guru dan memberi dampak positif bagi siswa.

Selain itu, sekolah ini mengalami kekurangan media pembelajaran. Aviciena tidak memiliki media pembelajaran bahasa Inggris. Kendala ini akan diatasi dengan memberikan beberapa media peraga pembelajaran untuk mendukung kegiatan story telling yang mudah digunakan seperti boneka tangan, buku, dan gambar.

\section{Metode}

Solusi yang ditawarkan pada sekolah ini adalah memberikan pelatihan dan pendampingan pada saat guru praktik. Pelatihan tentang story telling diberikan pada masing-masing kelompok. Pada kelompok 3 bulan-1 tahun, pelatihan diberikan menggunakan peraga boneka dan realia lain yang ada di sekolah dengan tema binatang. Story telling sangat sederhana diberikan oleh pengabdi sementara guru kelas memperhatikan dan sesekali terlibat. Setelah itu, guru diberi kesempatan untuk mempraktikkan story telling dengan media dan tema yang sama. Kegiatan ini fokus pada memainkan peran binatang dengan suara khas masing-masing binatang dan memberikan muatan cerita singkat.

Pada kelompok batita 1-2 tahun, pelatihan memanfaatkan buku cerita binatang bergambar milik sekolah yang sudah memiliki tulisan cerita bilingual, bahasa Indonesia dan Inggris. Buku ini beberapa kali digunakan guru untuk bercerita dalam bahasa Indonesia sehingga guru sudah cukup hafal isinya. Story telling sederhana dan singkat diberikan menggunakan buku tersebut. Fokus story telling pada kelompok ini adalah melatih guru bercerita singkat dengan bahasa yang sangat singkat, pengenalan kosa kata, dan improvisasi cerita berdasarkan gambar.

Pada kelompok batita 2-3 tahun, pelatihan diberikan menggunakan buku cerita milik pengabdi bertema kendaraan. Pelatihan diawali dengan berinteraksi lebih dekat dengan siswa karena pada kelompok ini siswa sudah mampu lebih berinteraksi daripada dua kelompok sebelumnya. Pertanyaan tentang sepeda motor diberikan pada siswa dengan respon siswa tertarik untuk mendengarkan cerita. Fokus story telling pada kelompok ini adalah pengenalan kosa kata, improvisasi cerita berdasarkan gambar, dan bercerita dengan bahasa yang lebih kompleks dari kelompok batita 1-2 tahun.

Pendampingan dilanjutkan pada kelompok balita 3-4 tahun yang digabung dengan kelompok TK A 4-5 tahun. Alasannya adalah kemampuan bahasa rata-rata kedua kelompok ini hampir sama diantaranya, mampu berinteraksi sederhana dengan orang baru, mampu mendiskripsikan gambar sederhana, dan bercerita menggunakan gambar serial. Tema pada kelompok ini adalah kendaraan bis. Pelatihan diawali dengan bernyanyi The Bus Song. Fokus story telling pada kelompok ini adalah pengenalan kosa kata, bercerita menggunakan naskah pada buku, improvisasi cerita berdasarkan gambar, dan penekanan pesan moral.

Pada kelompok TK B 5-7, pelatihan dilakukan menggunakan buku dengan tema kerajaan, A Little Princess. Siswa pada kelompok ini lebih kooperatif dan interaktif pada suatu kegiatan dan mampu membaca dengan sedikit bantuan. Pengabdi memberikan contoh story telling. Pada bagian tengah cerita, pengabdi memberi kesempatan guru untuk melanjutkan cerita. Fokus story telling pada kelompok ini adalah pengenalan kosa kata, bercerita menggunakan naskah buku, dan penekanan pesan moral. 
Rangkaian pengabdian diakhiri dengan pemberian donasi buku dalam bahasa Inggris. Buku ini diharapkan mampu menambah fasilitas buku bilingual yang ada di sekolah. Buku yang didonasikan diterbitkan oleh penerbit dari luar negeri, berbahasa Inggris, dan bersampul tebal dengan harapan buku tersebut lebih tahan lama, menarik minat membaca, dan menambah cross culture understanding.

\section{Hasil}

Pendampingan dilakukan secara klasikal berdasarkan kelompok usia. Kelompok ini terdiri dari bayi 3 bulan -1 tahun, batita 1-2 tahun, batita 2-3 tahun, menggabungkan kelompok balita 3-4 tahun dan TK A 4-5 tahun, dan TK B 5-7. Peserta pengabdian adalah guru berjumlah sepuluh. Setelah pendampingan selesai, guru diberi kesempatan selama 2 pekan untuk mempraktikkan story telling tanpa pendampingan. Setelah itu, diskusi dilakukan pada masing-masing guru kelompok untuk berbagi pengalaman dan membahas kendala selama 2 pekan tersebut.

Pengabdian masyarakat dilakukan pada tanggal 30 April, 3 Mei, dan 14 Mei 2019. Pada tanggal 30 April dan 3 Mei 2019, kegiatan pengabdian adalah pelatihan dan pendampingan story telling dengan alokasi waktu rata-rata 1 jam setiap kelompok. Pada tanggal 14 Mei 2019 dilakukan review berupa diskusi dengan masing-masing guru dengan alokasi waktu rata-rata 30 menit setiap kelompok.

Diskusi dilakukan dengan 2 kelompok kecil. Kelompok pertama adalah guru batita. ada kelompok 3 bulan-1 tahun, guru berbagi pengalaman tentang penggunaan media cerita lain yang ada di sekolah yaitu bola, lego, dan boneka. Guru bercerita tentang warna dan sifat gemar berbagi. Karena siswa pada kelompok ini masih bayi, belum nampak respon bahasa yang terlihat. Namun demikian, pengenalan bahasa Inggris tetap perlu diberikan sebagai input pengembangan bahasa pada tahapan berikutnya. Pada kelompok batita 1-2 tahun, guru berbagi pengalaman bercerita masih dengan tema yang sama yaitu binatang dengan pesan moral patuh pada orang tua. Guru sudah mampu bercerita dengan lebih percaya diri, mengucapkan kosa kata dengan lebih benar, dan menggunakan intonasi cerita yang lebih fasih. Respon siswa adalah siswa mampu menirukan beberapa kosa kata bahasa Inggris. Pada kelompok batita 2-3 tahun, guru berbagi pengalaman bercerita dengan tema angka dengan pesan moral gemar menjaga kebersihan. Respon siswa adalah siswa mampu menirukan beberapa kosa kata bahasa Inggris, lebih semangat menjaga kebersihan ketika diingatkan pada cerita ini, dan antusias dengan story telling tema lain.

Diskusi kelompok kedua adalah guru balita yang digabung dengan TK. Pada kelompok balita 3-4 tahun dan TK A 4-5 tahun, guru berbagi pengalaman menggunakan buku The Little Princess. Hasilnya, guru mampu membacakan cerita secara keseluruhan dengan baik dan menyampaikan pesan moral cerita. Beberapa siswa mampu menceritakan kembali menggunakan bahasa Indonesia dan beberapa kata dalam bahasa Inggris serta mengulang pesan moral cerita menggunakan bahasa Indonesia. Pada kelompok TK B 5-7 tahun, guru berbagi pengalaman menggunakan buku dengan tema pemadam kebakaran. Hasilnya, guru mampu membacakan cerita dengan lancar. Pada bagian akhir cerita, guru memberikan beberapa pertanyaan kosa kata dalam bahasa Inggris dan meminta siswa menyimpulkan pesan moral cerita. Siswa mampu menjawab kosa kata dengan baik dan menyimpulkan pesan moral cerita dengan sedikit bantuan guru.

\section{Kesimpulan}

Kegiatan pendampingan guru untuk meningkatkan kemampuan story telling ini dapat berjalan lancar. Ketersediaan peserta untuk semangat belajar bahasa Inggris, pemanfaatan buku dan fasilitas sekolah, dan donasi buku merupakan faktor penting 
kegiatan ini. Selain itu, kemampuan guru untuk senantiasa sabar mendampingi siswa menjadi dasar pengembangan story telling baik guru maupun siswa

Beberapa kendala dapat diatasi dalam kegiatan ini. Kendala pertama adalah kepercayaan diri guru untuk membawakan story telling. Hal ini bisa diatasi dengan memberikan contoh cerita sangat sederhana dan memberikan pendampingan individu pada guru. Kendala kedua adalah kurang media belajar bahasa Inggris. Hal ini diatasi dengan memberikan donasi buku story telling ke sekolah. Kendala ketiga adalah belum ada program sekolah terkait bahasa Inggris. Solusi yang dirumuskan adalah diskusi dengan kepala sekolah tentang program sederhana yang memungkinkan untuk dikembangkan seperti fun drawing, fun gardening, and fun cooking untuk disesuaikan dengan program sekolah yang berbasis sekolah alam.

\section{Daftar Pustaka}

[1] Garvie, E. (1990). Story As Vehicle : Teaching English to Young ChildrenMultilingual Matters. Philadelphia: Multilingual Matters Ltd.

[2] Linse, C. T. (2005). Practical English Language Teaching: Young Learners. New York: McGraw-Hill Companies, Inc.

[3] Pertiwi, D. R. (2019). Pengenalan Komponen Otomotif dalam Bahasa Inggris bagi Pemuda Daerah Wonokromo II. Jurnal Pengabdian Masyarakat Bidang Teknologi, Kacanegara. Volume 2, No. 1, 2019.

[4] Rich, S. (2014). International Perspectives on Teaching English to Young Learners. New York: Palgrave MacMillan. 